\title{
Being a Kakehashi: A Case Study of the Link Between Teacher Beliefs and Student Engagement
}

\section{Robyn Moloney}

\author{
Macquarie University
}

Schools and universities frequently struggle to nourish sustained language learning in their advanced students. There is limited research investigating the elements of effective teaching, which particularly support advanced language learning performance. This article investigates the apparent effect of language teacher beliefs in shaping development of advanced student performance on a Japanese speech-writing task in the Australian senior secondary school context. It is informed by both the analysis of a narrative written by the teacher and data collected in students' engagement with the task. It seeks to highlight the active role of teacher beliefs conveyed to students in contributing to advanced achievement in Japanese language learning.

グローバルな時代に見受けられる、マルチリンガリズムの経済的、社 会的、文化的価值を持ってしても、学校や大学は、度々上級の生徒や学 生たちに高度な言語学習の機会を提供することの困難に直面する。高度 な言語学習をサポートする効果的な教授法の各要素に焦点を当てた研究 は少ない。この論文 では、オーストラリアの高校で、言語の先生の信念が 生徒の日本語のスピーチライティングの課題のパフォーマンスにどのよう な影響を与えるか検証する。課題につい先生が書いた 文章の 分析と 生徒のその課題への取り組みの度合いを示すデータを比べる。高度な 日本語の言語習得において先生の信念がいかに多大な役割を担うことを 示すものである。

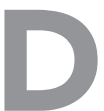

espite frequent calls for multilingual graduates, attrition in school and university language learners is common, and faculties struggle to retain their best advanced learners (Lo Bianco \& Slaughter, 2009). Factors which shape performance in advanced language learners, such as how to maximise adolescents' sense of identity as language users, and the impact of teacher beliefs on student motivation need to be better understood (Bramwell, Reilly, Lilly, Kronish, \& Chennabathni, 2011). This case study investigates the motivating role of a teacher's conveyed beliefs, in shaping her students' performance on a class task.

\section{Literature Review}

This study is informed by a sociocultural approach, which considers language learners as members of social collectives in social interaction (Van Lier, 2000). Higher order thinking skills, with meta-awareness of cognitive processes are vital in moving from concrete to more sophisticated language use. Advanced language learning must include sociocultural and emotional competence, and ability to express one's personality in the language (Lever, Ehrman, \& Shechtman, 2005). Advanced language learners can memorize and use structures in communicative practice readily (Deveau, 2006).

Teachers' beliefs, often formed from their own schooling, directly affect approaches to teaching (Beijaard, Verloop, \& Vermunt, 2000). The teacher in the Japanese classroom of this research study, Mizoshiri, has published a reflective narrative (Mizoshiri, 2013) of her professional development. This narrative, while outside the research data, is integral to the study, thus it will be reviewed in some detail.

Mizoshiri (2013) narrates memories of her own stimulating primary school classroom in Australia as a learner of Japanese:

I can vividly remember sitting in the Japanese room at low blue tables with blue Zabuton cushions. The room was covered in colourful posters and items from Japan. We coloured hiragana cards, learned numbers and songs and I was introduced to Japanese culture and language. (p. 100).

Mizoshiri notes that her love of real-world language links was initiated early through correspondence with a child in Japan, followed by exchange trips, speech contests, and work in Japan. Her beliefs influence both the process and the product of learning: "Japanese was my overriding passion, and my goal was to become a fluent speaker" (p. 101). As a young adult bilingual, Mizoshiri positioned herself between two languages and two cultures as she created a new hybrid identity for herself. Mizoshiri worked in Japan as an English teacher in schools, and discovered a "passion to teach young people" (p. 101). Mizoshiri positioned her Japanese ability, or her L2 Self (Dornyei, 2009), as an import- 
ant element of her adult future self, in her private life, through marriage, and in her career pathways. Mizoshiri's identity as a Japanese language user was constructed around her motivation to express herself, and to be a member of the Japanese language community. Mizoshiri exemplifies the academic performance which occurs for students who can produce well elaborated, vivid pictures of future selves (Leondari, Syngollitou, \& Kiosseoglou, 1998).

Mizoshiri wants her students also to experience the excitement of Japanese embedded in their life-world, and she takes responsibility for facilitating that:

I want every student to grow as a curious excited and open-minded individual interested in the world around them. I believe in intercultural language learning as a life-long activity and I hope that some of my students start their journey in my Japanese class . . I I aim to be a $k a-$ kehashi (bridge) or conduit, linking my students with Japan. (Mizoshiri, 2013, p. 102).

Mizoshiri projects her beliefs into her creative pedagogy: "I believe that I have a responsibility to educate high achievers to think beyond the Japanese classroom, to link their knowledge with other areas of the curriculum, and to grapple with global issues."(2013, p. 103)

Mizoshiri's teacher beliefs are focussed in three areas of pedagogy: first, the relevance of real-world links through autonomous learning; second, the alignment of identity with language learning; and third, stimulating high-order thinking.

While there has been substantial research attention to language teachers, there is, as noted, limited current research examining the intersection between language teacher beliefs and learner motivation and achievement. The study asked the research question, whether and how Mizoshiri's beliefs could be seen as conveyed and reflected in student attitude and performance on a speech-writing task.

\section{Description of Task}

The task was designed by the teacher to achieve three goals: to demand higher order thinking in writing and speaking, to display students' autonomous learning, and to focus on the individual L2 self. These goals reflect Mizoshiri's beliefs as noted in her narrative. The text of the task description given to students was as follows:

In Japanese you are going to give a brief ( 2 minute) presentation in Japanese to teenagers at your sister school about your favourite JPOP band/artist and the song which means most to you. You must try to incorporate grammar struc- tures learnt this year. And remember ... Challenge yourself!

Pre-task scaffolding in class included revision of useful linguistic structures and provision of some samples of previous students' work.

\section{Methodology \\ Research Site and Participants}

The data collection for this qualitative case study took place in 2013 in a NSW Government single-sex girls' secondary school, in Sydney, Australia. Approximately $90 \%$ of students in the school (from personal communication with school principal) come from culturally and linguistically diverse family background. That is, they may be heritage speakers of another language such as Chinese, Korean, or Vietnamese. Entry to the school is by a competitive academic public examination. Year 11 is the fifth year of secondary school, and students are aged 16 to 17. Ethics procedures included obtaining consent from the school principal, parents and students.

All students in the class (11) participated in the task as part of their regular classroom program, but only 8 students consented to participate in the research data collection. As noted, the teacher is Sally Mizoshiri, Anglo-Australian, aged 25 to 35, and her permission has been given to be identified. Under university ethics procedures, all students and their parents gave consent to participate. All students in the data below are de-identified, and referred to below as S1, S2, S3, and so on.

\section{Data Collection}

Qualitative data were collected over 5 months, and included three sets of data:

1. students' written reflection mid-task (July, 2013, N=8),

2. students' written speech texts (August 2013, $\mathrm{N}=8$ ),

3. student' reflection in one 20-minute audio-recorded focus group post-task (November 2013, $\mathrm{N}=6$ ). The attrition in participants was due to the absence of two participants on the day of the focus group interview.

\section{Data Analysis}

The student mid-task reflections, the speech texts, and the transcription of the focus group interview were read, analysed and triangulated using thematic content analysis. The purpose of different data sources was to capture different perspectives on the 
student learning process, and to enable triangulation. To support the credibility of the findings, all data, plus the development of the interpretation, were shared with the teacher, in three iterations, for checking and perceptions.

\section{Findings}

We have noted that three focuses in the teacher beliefs are facilitating real-world links, the alignment of personal identity with study, and the necessity of higher-order thinking in advanced language learning. It was the goal of the analysis to investigate whether and how these beliefs are conveyed and active in the students' perception of their learning.

In the mid-task reflections, in explaining their rationale for their choices, four of the eight students noted that they had chosen a theme song of a Japanese animation (anime), due to an emotional attachment to Japanese anime from their childhood. Other rationales included connection with personal experiences while on exchange in Japan, the song's musical qualities, nostalgia, and adolescent idealism ( $\mathrm{S} 1$ wrote that "there is a very positive and encouraging meaning behind the lyrics"). Students reported they were struggling with constructing language to express personal and emotional issues in Japanese: "Coupled with new grammar learned in class as well as relatively new vocabulary, it can be frustrating at times trying to phrase things in a way where meaning has not been lost or misinterpreted" (S8).

In analysing the final speech texts, the teacher beliefs become evident as activated in student performance: the role of autonomous access to Japanese resources, the enjoyment of Japanese media, and the satisfaction of being able to express a personal response to lyrics. A number of students have interacted with Japanese culture from an early age out of school. For example:

私が五才ぐらい時セーラームーンは私の一ばん好き なアニメでした。子どもの時この歌は私にせいぎとロ マンスをおしえてくれました (When I was about 5 years old, Sailor Moon was my favourite anime. When I was a child, the song taught me justice and romance). (S2)

This task affords them the opportunity to display their cultural knowledge and identity as an integral part of their linguistic development. Secondly, the song choices of four students (S2, S3, S4,\& S6) are connected with their independent enjoyment of animation or other media.

\footnotetext{
一番好きなアニメーションはジブリスタジオの「せん とちひろのかみかくし」ですから、一番すきなうたは 「いつもなんどでも」です (As my favourite anima-
}

tion is Sen to Chihiro no Kamikakushi [Spirited Away], I like its main theme song Itsumo Nandodemo [Anytime, Many Times]). (S6)

Students' autonomous literacy choices play a role in shaping language development and sense of identity in Japanese (Lo Philip, 2010; Moloney \& Oguro, 2015). The students' texts, using the pronoun 私たち (us, we) and みなさん (everyone), show membership of a community of Japanese users, through literacies and language. Thirdly, the choices also reflect students' willingness to engage with higher order thinking, comprehension and language construction. They comprehend the complex lyrics of an authentic text, and construct a personalised statement of their alignment with the songs' content, in adolescent aspirations, future hopes, and idealism. For example:

かしのメッセージはいのちにみらいにあなたのあたら
しいみちをさがすことです。今、大人じゃなて高校
生ですから、歌のメッセージは私たちにとてもみじか
です。(The lyrics contain a lot of meaning and
feeling. The message of the lyrics is that you
must find your own new way in your future. The
song is about high school students, not adults, so
it is close to us.) (S1)

S1 above appreciates the freedom to choose a song aligned with her age group, rather than a text chosen by the teacher. All eight speech texts show an affective involvement, with the desire to communicate motivating their performance. The linguistic structures used are those prescribed for study in the Stage 6 Continuers Syllabus Japanese (NSW BOS, 2009). Students are using the structures with considerable originality to achieve sophisticated self-expression at a level which may be expected in the highest level of Year 12 students.

\section{Student Focus Group Interviews}

Themes emerging from the post-task focus group data largely triangulate findings from the mid-task reflection, the speech texts, and reflect teacher beliefs. Students firstly confirm their enjoyment of producing a meaningful text: "I wanted to do something that was personal to me. I was able to tell my story, basically, through it" (S2). This student identifies a sense of L2 self, in her ability to tell her story. She reflects Mizoshiri's desire for students to find their individual identity through their Japanese study. A number of students noted that the task afforded a more 'natural' use of their Japanese. S5 said the benefit of the task was that "when I go to Japan, and interact with Japanese people, I can do it in a more natural way. It gave me more confidence. It 
confirmed that I could actually speak Japanese". The task facilitates Mizoshiri's desire to act as a kakehashi (bridge), linking her students with real-world Japan and the self-efficacy of being a confident user of Japanese (Tanaka, 2004). S1 echoes Mizoshiri's belief in acquiring a real-world view: " ... when you learn a language, you don't just learn basic skills, you have to learn about the society and culture." S5 similarly echoes, that "... learning a language isn't like learning another subject like maths or science. ... just walking around in the street, you might hear people speaking Japanese ... So you're always constantly thinking or learning."

Mizoshiri believes that even young students are capable of independently using a variety of Japanese learning resources (Mizoshiri, 2013). S2 suggested that this has increased her vocabulary, and that she displayed some of this in her speech: "Although the speech is formal, I put in some modern language, that young people would use ... I've watched dramas, anime, and it was useful".

Student S1 confirms that students have absorbed Mizoshiri's demand for higher order thinking: "In junior years we learn the basic skills, but then later we have to think critically about expressing our opinions in Japanese".

In sum, we observe the teacher beliefs conveyed and activated in student attitudes and performance. The task exemplifies teacher beliefs in independent self-expression, in higher order thinking, in aligning affect and identity, and the students' responses rise to these challenges.

\section{Discussion and Conclusion}

While this case study is limited in size, gender of participants, and school environment, it illustrates the alignment of teacher beliefs, conveyance of those beliefs through pedagogy, and students' motivated linguistic achievement. This knowledge contributes to understanding factors involved in advanced language learning.

These students are constructing an adult future self as Japanese users, and this task affords an effective expression of this self. The study may serve as a pilot to a broader study, which could include a variety of school contexts and teachers, mixed gender, and different languages. Such research informs language teacher education, and specifically further research attention to effective pedagogy for the advanced language learner.

\section{References}

Beijaard, D.,Verloop, N., \& Vermunt, J. D. (2000). Teachers' perceptions of professional identity: an exploratory study from a personal knowledge perspective. Teaching and Teacher Education, 16, 749-764.

Board of Studies NSW. (2009). Japanese continuers stage 6 syllabus. Sydney, Australia: Board of Studies NSW.

Deveau, T. (2006). Strategies for gifted second language learners. Academic Exchange Quarterly, 10(1), 265-271.

Dörnyei, Z. (2009). The L2 motivational self system.In Z. Dörnyei \& E. Ushioda (Eds.), Motivation, language identity and the L2 self. (pp. 9-42) Clevedon, England: Multilingual Matters.

Lever, B.L., Ehrman, M.E., \& Shechtman, B. (2005). Achieving success in second language acquisition. Cambridge, UK: Cambridge University Press.

Leondari, A., Syngollitou, E., \& Kiosseoglou, G. (1998). Academic achievement, motivation and future selves. Educational Studies, 24, 153-163.

Lo Bianco, J., \& Slaughter, Y. (2009). Second languages and Australian schooling [Monograph]. Australian Education Review, 54. Camberwell, Australia: ACER Press. Retrieved from http://research.acer.edu.au/aer/8

Lo-Philip, S. W. Y. (2010). Towards a theoretical framework of heritage language, literacy and identity processes. Linguistics and Education, 21, 282-297.

Mizoshiri, S. (2013). Teaching Japanese to gifted and talented girls. In L. Harbon \& R. Moloney (Eds.), Language teachers' narratives of practice (pp. 100-110). Cambridge, UK: Cambridge Scholars' Publishing..

Moloney, R., \& Oguro, S. (2015). To know what it's like to be Japanese: A case study of the experiences of Heritage Learners of Japanese in Australia. In I. Nakane, E. Otsuji, and W.S. Armour (Eds.), Languages and identities in a transitional Japan (pp.121-140). New York, NY: Routledge.

Robyn Moloney teaches in the School of Education, Macquarie University, as a language teacher educator. She was previously a secondary school teacher of Japanese. Her research interests and publications include focus on language teacher development, intercultural language learning and pedagogy, heritage language

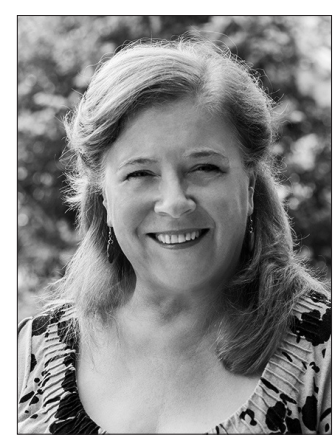
learners, and also the teaching of Chinese as a foreign language. 